\title{
INFLUENCE OF PURITY ON MICROSTRUCTURE AND STRENGTH CHARACTERISTICS OF REFRIGABLE MICROCOMPOSITES
}

\author{
N.A. Azarenkov, V.E. Semenenko, S.V. Lytovchenko, N.G. Styervoyedov \\ V.N. Karazin Kharkiv National University, Kharkiv, Ukraine
}

The influence of the purity of the source materials on the structural and dimensional stability of microcomposites obtained in the process of controlled invariant phase transformation is investigated. The influence of high-temperature post-crystallization heat treatment on the processes of cleaning and increasing the technological ductility of structural materials is considered. The possibility of their practical use is discussed.

For the further development of nuclear, thermonuclear energy, aerospace engineering, and mechanical engineering - clean, structural, and dimensionally stable materials are needed. As is known, radiation damage to materials is initiated at the atomic level, while macroscopic effects of structure degradation (coagulation of phases, creep, embrittlement) occur due to microstructural changes - the state of interphase boundaries, morphology of the second phases, their relationship with the matrix alloy component, concentration of linear and point defects [1-4].

An increase in the operating temperature of structural materials is possible due to the use of refractory metals as the basis. W, Ta, Nb, Mo possess high compatibility with nuclear fuel (uranium), however, pure refractory metals in terms of strength characteristics and radiation resistance cannot satisfy the requirements of the operation of new generation high-temperature reactors. An important structural component of materials in the core of nuclear reactors are carbide-forming elements of $\mathrm{Zr}, \mathrm{Ti}, \mathrm{Nb}$, which are part of reactor steels. $\mathrm{MeC}$ incorporation phases ( $\mathrm{TiC}, \mathrm{ZrC}, \mathrm{NbC}$ ), their structure during the irradiation process does not change significantly $[5,6]$. Carbide-forming elements and compounds based on them lead to an increase in heat and wear resistance, reduce the creep rate, and reduce radiation swelling. Structural materials with a stable finely dispersed microstructure under conditions of exposure to high temperatures and thermal shocks are required. At temperatures above $1500 \mathrm{~K}$, carbides are the most thermodynamically stable incorporation phases due to the presence of a strong covalent $\sigma$-bond formed by overlapping orbits $\mathrm{p}^{6}$, which determines the effectiveness of carbide high temperature hardening [5-8]. To date, insufficiently studied methods for increasing the heat resistance and wear resistance of materials due to heterogenization of the structure of carbide alloys on a refractory basis. Available data are limited mainly to systems with heterogeneous macro- and micromorphology, prone to coagulation at temperatures above $0.7 T_{\mathrm{mlt}}$ [9]. It is important to preserve strain hardening and inhibition of recrystallization processes. In this regard, studies of structurally stable materials, up to premelting temperatures, are of interest. In eutectic microcomposites, changes in the micro- and macromorphology of phases are possible during the process of controlled phase transformations.

Analysis of known state diagrams $\mathrm{Me}^{\mathrm{I}}-\mathrm{Me}^{\mathrm{II}}-\mathrm{X}$ shows that between volumetric cubic metal $\mathrm{Me}^{\mathrm{I}}$ (or solid solution based on it) and refractory phase formed by the incorporated element $\mathrm{X}$, metal $\mathrm{Me}^{\mathrm{II}}$ there are eutec- tics that can be seen as pseudo binary. In carbide alloys, composition changes are possible. Alloys W(Nb)-C$\mathrm{Me}^{\mathrm{IV}}-\mathrm{Zr}(\mathrm{Hf})$ can serve as an example, in which, under certain conditions, phase reactions can occur: $\lambda_{\mathrm{W}(\mathrm{Nb})}^{\mathrm{I}}+\mathrm{Me}^{\mathrm{IV}} \mathrm{C} \rightarrow \lambda^{\mathrm{II}}{ }_{\mathrm{W}(\mathrm{Nb})}+\mathrm{W}_{2} \mathrm{C}\left(\mathrm{Nb}_{2} \mathrm{C}\right)$. With an increase in temperature, metal carbides become hardening phases, which are prone to coarsening at homological temperatures of more than $0.7 T_{\mathrm{mlt}}$ of the base metal [10].

Structural materials with a stable highly dispersed microstructure under conditions of exposure to high temperatures and thermal shocks are required.

Well-known physical and chemical representations allow you to choose the optimal alloy compositions. It should be noted that the methods for increasing the heat and radiation resistance of materials due to heterogenization of the structure of carbide alloys on a refractory basis are insufficiently studied $[11,16]$.

The ambiguity of the literature data on the effect of crystallization conditions on the morphology, evolution and regularity of the structures of eutectic alloys containing highly entropic phases, prone to spheroidization of cellular-dendrite structures is known. The relevance of the development of highly dispersed structurally stable carbide alloys is due to the fact that carbide-forming refractory elements included in reactor steels increase heat resistance, reducing radiation swelling. In this respect, eutectic microcomposites obtained under the conditions of a controlled invariant phase transformation with a given morphology and a certain degree of dispersion are of interest, which is one of the main problems considered in this work. At the same time, the high melting points of refractory alloys cause certain difficulties in their creation and study. In addition, it is necessary to take into account the complex architecture of eutectic metal - the implantation phase, the faceted but not faceted shape of the phases of natural in-sute composites $[8,12,13]$.

The aim of the work is to study the influence of the purity of the starting materials on the dimensional stability of microcomposites obtained in the process of controlled invariant phase transformation and hightemperature heat treatment on the possibility of obtaining structurally stable bimonocrystalline materials, the possibility of their practical use.

\section{INITIAL MATERIALS AND EXPERIMENTAL TECHNIQUES}

$\mathrm{Ta}, \mathrm{Nb}, \mathrm{Mo}$, zirconium iodide, and carbon of spectral purity were used as starting materials. 
Eutectic alloys were used $\mathrm{Me}^{\mathrm{I}}-\mathrm{Me}^{\mathrm{II}} \mathrm{X}$, where $\mathrm{Me}^{\mathrm{I}}-$ $\mathrm{Ta}, \mathrm{Nb}, \mathrm{Mo}$ and $\mathrm{Me}^{\mathrm{II}}-\mathrm{Zr}, \mathrm{X}-$ carbon, volume fraction of carbides $-20 \ldots 45$ wt. $\%$ [5].

The production method is a controlled high-gradient zone recrystallization with the use of ring scanning of the electron beam $[\mathrm{MF}]$. High temperature vacuum rolling was used [DUO-135].

Structural studies - stereometric metallography, $\mathrm{X}$-ray diffraction [DRON-4M] and high-resolution electron microscopy [TEM] high resolution analyzes [JSM$200 \mathrm{CK}$ ] at an accelerating voltage of $200 \mathrm{kV}$ [4]. X-ray microanalysis was used Comebax-beam exit angle $40^{\circ}$, excitation voltage $15 \mathrm{kV}$, current through the sample $0.025 \mu \mathrm{A}$, diameter of the electron beam $\sim 0.8 \mu \mathrm{m}$. Bursting tests carried out in the temperature range $300 \ldots 2500 \mathrm{~K}$ (Instron) on samples cut from an alloy ingot by the electric spark method followed by electropolishing to remove distorted surface layers, the tensile speed $\sim 10^{-3} \mathrm{c}^{-1}$.

\section{RESULTS AND DISCUSSION}

In the process of high-gradient zone crystallization, a different form of crystallization front is observed.

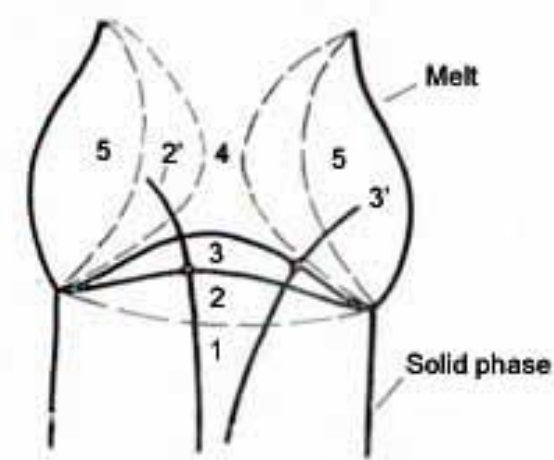

Fig. 1. Scheme of the shape of the crystallization front

As can be seen from Fig. 1, there is a curvature of the shape of the crystallization front under various conditions of zone melting (1-5): $\Delta T_{1}>\Delta T_{2}>\cdots>\Delta T_{5}$. The curves show the direction of movement of various points of the crystallization fronts at different temperatures and the movement of the melt zone. For the formation of ordered structures of eutectic alloys, the stability of a flat crystallization front (CF), which is determined from the relation

$$
\frac{G}{R}>\frac{\Delta T}{D} \frac{K}{K+(1-K)^{e^{-\Delta}}},
$$

where $\Delta T$ - crystallization range; $D, K$ - diffusion and distribution coefficients of the impurity, respectively; $\Delta=\delta_{\mathrm{K}} R / D$, where $\delta_{\mathrm{K}}-$ diffusion layer thickness in the presence of convection; $R$ - crystallization rate. It has been established that in the process of zone crystallization redistribution of impurity elements occurs, which significantly affects the solidification process and structural stability in the post-crystallization period. It is shown that even in the early stages of solidification, the formation of inhomogeneous, conglomerate structures is facilitated by the presence of interstitial impurities $(C$, $\mathrm{N}, \mathrm{O}$ ), the accumulation of which near the surface of the crystallization front and growing crystals prevents the nucleation and further joint (pair) growth of alloy phases (eutectics). It was determined that the critical content of these impurities responsible for concentration supercooling causes a violation of the planar $\mathrm{CF}$ and amounts to $10^{-1} \ldots 10^{-2}$ wt.\% depending on the magnitude of the temperature gradient created in the melt $G$. In the process of directed crystallization of refractory metal - carbon systems, the metal is purified by evaporation of volatile impurities, zone refining. The deoxidation of the matrix component was observed mainly due to the interaction of carbon and oxygen with the formation of volatile oxides and atomic oxygen [14]. It was determined that the content of the main metallic and gas impurities after the first two or three passes of the zone is sufficient for the formation of regular in-sute structures of the composite material. Pressure reduction in the working chamber $\left(<10^{-4}\right.$ Пa) led to a deeper purification of alloy ingots from oxygen, nitrogen $\left(<10^{-3}\right.$ wt. $\left.\%\right)$ and carbon $\left(\sim<10^{-3}\right.$ wt. $\left.\%\right)$.

It should be noted that in the case of using pure components obtained by electron beam melting, according to (1), a temperature gradient is sufficient for the formation of a flat $\mathrm{CF} G \approx 300 \ldots 400 \mathrm{~K} / \mathrm{cm}$ compared with the use of "dirty" components - the gradient is $500 \ldots 700 \mathrm{~K} / \mathrm{cm}$. Under conditions of high-gradient zone crystallization, an increase in $G$ decreases the leading distance leading to the crystallization of the carbide phase, decreasing the possibility of its dendrite branching and contributes to the creation of a flat photonic crystal, obtaining uniform (regular) spatially ordered structures. Under the conditions of directed crystallization, the size, shape, and dispersion of phases are controlled by the quantities $G$ and $R$.

An analysis of the solidification conditions shows that the redistribution of atoms can only occur in a supercooled liquid layer (below $T_{\mathrm{E}}$ ). $d_{\text {hyp }}=\Delta T_{1} / G$, where $\Delta T_{1}$ - hypothermia. According to the above calculations, in the case of high-gradient crystallization $d_{\text {hyp }}=\sim 10^{-2} \ldots 10^{-3} \mathrm{~cm}$, the diffusion layer is limited by the width of the super-cooled layer. This can explain the deviation of $\mathrm{n}$ in the ratio $\lambda=A \cdot R(\lambda$-dispersion of the eutectic composite) from the theoretical value $n=0.5$.

A study of the dislocation structure of MCM showed that growth dislocations originate at misfit dislocations located at interphase boundaries. In regular MCM, a certain relationship is observed between the direction of growth (DG) and the planes (DP) of phase conjugation: $[112] \mathrm{Ta}(\mathrm{Nb}) \|[010] \mathrm{Ta}_{2}\left(\mathrm{Nb}_{2} \mathrm{C}\right)$, partition surface $\mathrm{DP}\|[110] \mathrm{Ta}(\mathrm{Nb})\|[001] \mathrm{Ta}_{2}\left(\mathrm{Nb}_{2} \mathrm{C}\right)$.

It was determined that at the beginning of the growth of the MCM, a partial relaxation of elastic strains takes place and then dislocations arise [15]. According to TEM, the nature of the contrast indicates that in the system Mo-ZrC Burgers vector $b=\frac{a}{2}\langle 110\rangle$ in the plane (111). The network of epitaxial dislocations observed on the phase surface extends to a depth $\sim 24 \ldots 45 \mathrm{~nm}$. 


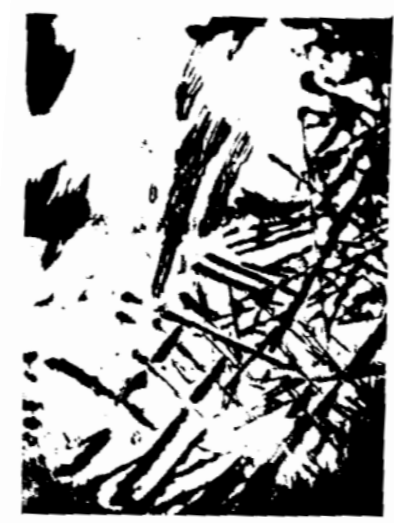

$a$

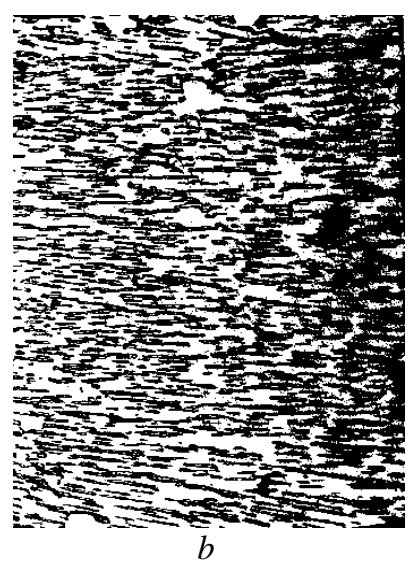

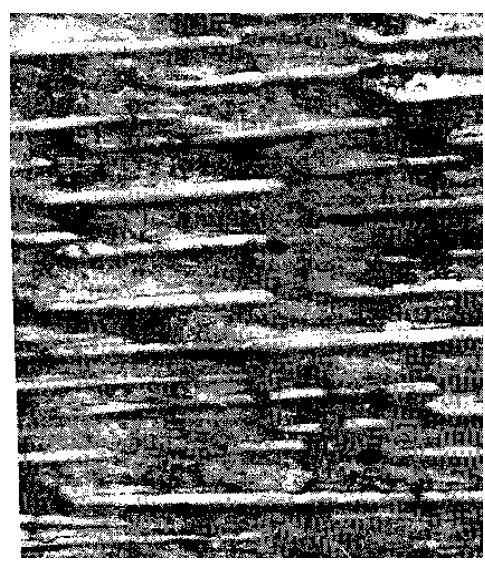

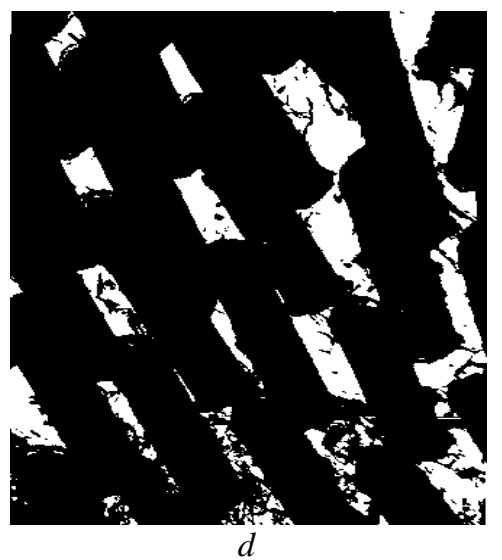

Fig. 2. Microstructure of eutectic composites (MCM) obtained by the recrystallization zone:

$a$-isotropic structure of the eutectic alloy $\mathrm{Mo}-\mathrm{ZrC}, x 900 ; b$ - regular structure $\mathrm{Nb}-\mathrm{Nb}_{2} \mathrm{C}$,

longitudinal section, $x 2000 ; c$-regular structure Ta-Ta 2 , $x 1500 ; d-\mathrm{Ta}_{-} \mathrm{Ta}_{2} \mathrm{C}$ transverse section, $x 5000$

An analysis of the structure of MCM showed that in the case of sporadic violation of regular growth, an increase in the density of linear dislocations and local defects is observed, which is accompanied by a change in the differentiation of the $\lambda$-composition, causing an increase in the density of dislocations $\rho_{d}$ in the metal matrix from $10^{7}$ to $\rho_{d} \geq(1 \ldots 8) \cdot 10^{9} \mathrm{~cm}^{-2}$.

For regular MCM with controlled annuel (aging $5 \ldots 10 \mathrm{~h}, 800 \ldots 1300 \mathrm{~K}$ ) oriented lamellar (in the system $\mathrm{Mo}-\mathrm{C}$ ) and fibrous (Ta-C) carbide phases; moreover, small precipitation of carbides in the matrix was practically absent (Fig. 2).

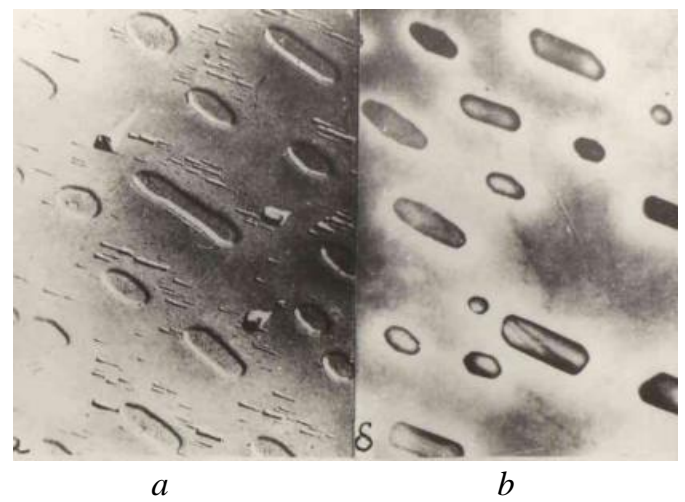

Fig. 3. Microstructure MCM Ta-Ta ${ }_{2}$ C before annealing (a) and after annealing (b), TEM
The latter is explained by the fact that carbides released from a supersaturated solid solution are isomorphic to the fibers and carbide plates of the corresponding eutectics, the release of excess carbon atoms on them is energetically more favorable, since there is no need for the formation of new interfaces [17]. As a result of such epitaxial growth of plates (layers on the finished surfaces of the hardening phases), diffusion "pumping" of carbon occurs. According to Comebax data, it is determined that the phase region adjacent to large eutectic plates turns out to be free from the release of particles of the excess phase. Layer-by-layer growth correlates with a faceted growth phase leading to crystallization phase. This phenomenon is observed at a distance of a few microns, which is characteristic of the heterophase structure of the studied systems. Table 1 shows the results of studies of impurity concentrations and lattice parameters of alloy components. The table shows the concentration of impurities: $C_{\mathrm{init}}, C_{\mathrm{dc}}, C_{\mathrm{dc}+a n n}-$ in the initial, directionally crystallized, directionally crystallized and annealed microcomposition, $a$ - lattice parameters.

As can be seen from Table 1, the best cleaning results are observed in the Mo- $\mathrm{ZrC}$ system due to the presence of a strong carbide former $(\mathrm{Zr})$ : the content of carbon impurities in the molybdenum matrix was $\sim(3 \ldots 5) \cdot 10^{-4} \%$, which corresponds to the best results of complex metal cleaning (Fig. 3). 
Table 1

The content of interstitial impurities and matrix lattice parameters determined at various stages of heat treatment

\begin{tabular}{|c|c|c|c|c|c|c|c|c|}
\hline \multirow[t]{2}{*}{ Material } & \multicolumn{6}{|c|}{ The impurity concentrations } & \multicolumn{2}{|c|}{$\begin{array}{c}\text { The lattice } \\
\text { parameters, } \mathrm{nm}\end{array}$} \\
\hline & $\mathrm{H}_{2}$ & $\mathrm{O}_{2}$ & $\mathrm{~N}_{2}$ & $C_{\text {init }}$ & $C_{\mathrm{dc}}$ & $C_{\mathrm{dc}+\text { ann }}$ & $a_{\mathrm{dc}}$ & $a_{\mathrm{dc}+\mathrm{ann}}$ \\
\hline $\begin{array}{l}\mathrm{Nb} \text {, the electron } \\
\text { beam melting }\end{array}$ & 0.0014 & 0.008 & 0.002 & 0.053 & - & - & - & - \\
\hline $\mathrm{Nb}-\mathrm{C}$ & - & - & - & 2.0 & 0.0036 & 0.00031 & 0.3308 & 0.3294 \\
\hline $\begin{array}{l}\text { Ta, the electron } \\
\text { beam melting }\end{array}$ & 0.0012 & 0.0046 & 0.003 & 0.07 & - & - & - & - \\
\hline Ta-C & - & - & - & 0.86 & 0.0025 & 0.00015 & 0.3306 & 0.3303 \\
\hline $\begin{array}{l}\text { Mo, the electron } \\
\text { beam melting }\end{array}$ & 0.001 & 0.002 & 0.001 & 0.02 & - & - & - & - \\
\hline Mo-C, eutectic & - & - & - & 2.65 & 0.0015 & $\begin{array}{c}0.0003+ \\
0.0005\end{array}$ & 0.31483 & 0.31486 \\
\hline $\begin{array}{l}\text { Mo-ZrC, } \\
\text { eutectic }\end{array}$ & - & 0.001 & - & 1.8 & 0.001 & 0.0001 & - & - \\
\hline
\end{tabular}

Experimental studies of the heat resistance of refractory carbide microcomposites, a comparative analysis of the deformation and fracture of MCM with a regular structure. The latter are bimonocrystalline materials carbide whiskers embedded in a refractory single-crystal matrix $\left(\rho_{\mathrm{d}} \sim 10^{2} \mathrm{~cm}^{-2}\right)$.

According to the TEM data, the deformation of the MCM at room temperature begins with the slip of dislocations in the metal matrix. Sliding dislocations are delayed near the matrix-reinforcing fiber of the carbide phase, as a result of which an accumulation of dislocations forms near the fiber-matrix interface (Fig. 4,a). The analysis shows that, in the presence of a strong interphase boundary characteristic of the studied MCMs, dislocation traversal of extended carbide particles is much more complicated compared to spherical particle traversal. Under stress growth conditions, active dislo-

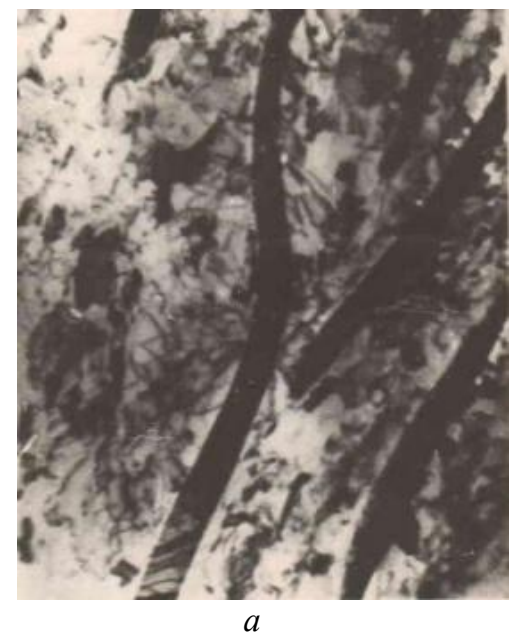

cations moving in the matrix interact with the stress field of interfacial dislocations, the length of which coincides with a distance of $\sim 40 \ldots 80 \mathrm{~nm}$ between dislocations at the phase boundaries [15].

Typically, fiber fragmentation begins when the tooth yields stress $(\sim 2 \%$ strain, system $\mathrm{Ta}(\mathrm{Nb})-\mathrm{C})$. Simultaneously with the fragmentation of the fibers (see Fig. 4,b), the destruction of the MCM does not occur, since, due to strain hardening, the matrix perceives a part of the load that the fiber previously performed. Refractory MCM with extended carbide fibers (the ratio of length 1 to diameter reaches $\sim 1000$ ) can withstand multiple crushing until they reach a critical length. The formation of submicrocracks occurs, first of all, in parts of the slip planes, where the shear is inhibited by a solid carbide obstacle.

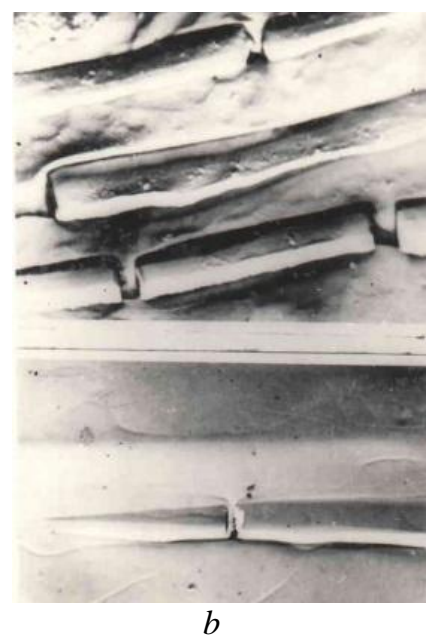

Fig. 4. Microstructure of deformed MCM: a-dislocations near carbides, x12000; $b$-crushing of carbide fibers and slip lines, $x 800$

In the Mo- $\mathrm{ZrC}$ system, deformation of the molybdenum matrix occurs in the $\langle 110\rangle$ direction along the planes (110). Two types of slip bands were found - uniformly distributed over the entire longitudinal section of the sample and localized near the fiber crushing sites. With an increase in dispersion, the slip bands of the first type are less pronounced, which is due to the effect of "constraint" of the matrix. For very thin fibers $(\leq 1 \mu \mathrm{m})$ with an increase in the degree of deformation, bands of rotational discharges up to $0.2 \mathrm{~mm}$ wide were observed, at the front of which the fibers were destroyed due to bending or twisting similarly [18-20]. At high temperatures (more $0.7 T_{\mathrm{mlt}}$ ) new slip planes are activated in the matrix and carbide phases, differences in crystallographic features of slip in the (110) and (100) planes in the $\langle 110\rangle$ direction, which are most characteristic for 
the systems under study, disappear in carbides. Sliding is carried out along one of the tightly packed planes in accordance with the direction of extension.

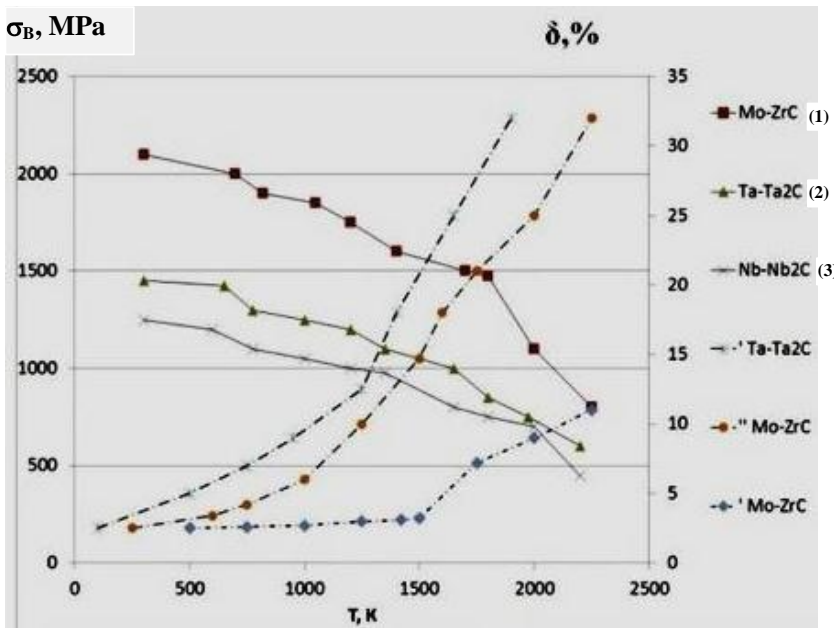

Fig. 5. Temperature dependence of the strength and ductility of MCM (1-Mo-ZrC; $2-\mathrm{Ta}_{-} \mathrm{Ta}_{2} \mathrm{C}$; $3-\mathrm{Nb}-\mathrm{Nb}_{2} \mathrm{C}$ ) ('- initial, ’’- after annealing)

The metallographic analysis of the MCM shows that during discontinuous testing in some parts of the samples, dislocation sections interacting with carbides were found to form Cotrell-Lomer type barriers, dislocation plexuses are formed - effective obstacles for dislocation movements elongated along the slip direction in the planes of type (110) (Fig. 6).

According to TEM, the dislocation density of molybdenum single crystals deformed by $20 . .40 \%$ is $\rho_{\mathrm{d}} \sim 10^{10} \ldots 3 \cdot 10^{11} \mathrm{~cm}^{-2}$, whereas in a micro composite Mo-ZrC under the same conditions $\rho_{\mathrm{d}}=10^{13} \mathrm{~cm}^{-2}$.

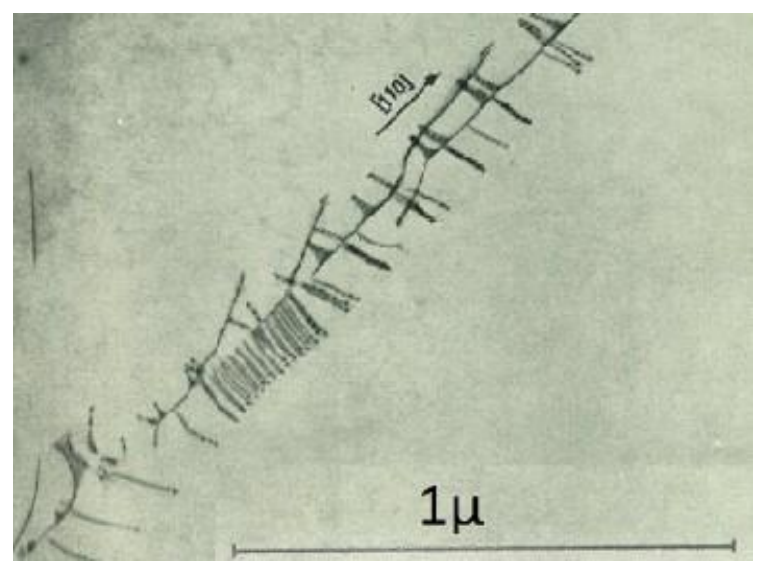

Fig. 6. Barriers of Cottrell-Lomer

The measured microhardness of molybdenum during the process of the same type of deformation varied from 1400 to $2500 \ldots 2600 \mathrm{MPa}$, while the MCM increased to 3500 ...3700 MPa. The results obtained indicate strain hardening of the matrix, which contributes to its greater contribution to the composition hardening mechanism of refractory MCM at elevated temperatures (Fig. 5). It should be noted that dispersion hardening was observed at $T \leq 1400 \ldots 1500 \mathrm{~K}$. It was determined that the microhardness values correlate with the data of short-term mechanical tests (Table 2). As can be seen from Table 2 , the hardness of the MCM significantly exceeds the corresponding values of the most heat-resistant cast alloys. The Mo-ZrC microcomposite with a volume fraction of the carbide phase of $20 . .25$ vol.\% a microhardness that is at the level of the highest strength tungsten alloys of the $\mathrm{W}+(\mathrm{Ti}, \mathrm{Zr}, \mathrm{W}) \mathrm{C}$ type with a cast structure.

Table 2

Microhardness of refractory microcomposites

\begin{tabular}{|c|c|c|c|c|c|c|c|}
\hline \multicolumn{2}{|c|}{ Matrix } & \multicolumn{2}{c|}{ Carbide } & \multicolumn{4}{c|}{ Eutectic } \\
\hline $\mathrm{Nb}$ & Mo & $\mathrm{Nb}_{2} \mathrm{C}$ & $\mathrm{ZrC}$ & \multicolumn{2}{c|}{$\mathrm{Nb}_{2} \mathrm{Nb}_{2} \mathrm{C}$} & \multicolumn{2}{c|}{ Mo-ZrC } \\
\hline 80 & 650 & 8200 & 26000 & 1 & 2 & 1 & 2 \\
\hline$H_{\mu}$ & - & - & - & 1800 & $2540 \ldots 3000$ & 4800 & $8900-9200$ \\
\hline
\end{tabular}

Table shows: 1 - cast structure, 2 - directionally crystallized microcomposites of various dispersion.

During annealing $\left(0.6 \ldots 0.8 T_{\mathrm{mlt}}\right) H_{\mu}$ value changes by less than $5 \ldots 10 \%$, the main load in the process of deformation of the MCM at high temperatures is carried by high-strength whiskers of carbides. As can be seen from Fig. 3, postcrystallization annealing of MCM with a regular microstructure $(T=1400 \mathrm{~K}, 3 \ldots 5 \mathrm{~h})$, leading to the cleaning of the matrix of carbon and embrittle carbides $\left(\mathrm{Mo}_{2} \mathrm{C}\right.$ in system $\left.\mathrm{Mo}-\mathrm{ZrC}\right)$, causes an increase in ductility on $10 \ldots 35 \%$.

\section{CONCLUSIONS}

As a result of controlled zone recrystallization of refractory carbide alloys using initial metals of technical purity, two-phase instability, dendrite phase growth, and the formation of a cellular disordered structure are observed.

It is determined that the critical content of impurities responsible for concentration supercooling causes a violation of the planar crystallization front, is $10^{-1} \ldots 10^{-2}$ wt. $\%$ depending on the magnitude of the temperature gradient created in the melt $G$.

An increase in the temperature gradient at the liquidsolid interface to $450 \mathrm{~K} / \mathrm{cm}$ leads to the formation of regular, spatially ordered, highly dispersed alloy structures.

As a result of high-temperature post-crystallization annealing of MCM, a perfect bimonocrystalline structure was formed.

Effective purification of carbon and embrittlement carbides as a result of high-temperature postcrystallization annealing increases the technological plasticity of carbide microcomposites by $10 \ldots 35 \%$, which makes them possible to use.

The obtained finely dispersed materials are of interest in the field of radiation materials science in terms of increasing resistance to high-temperature radiation swelling, due to the absence of transverse grain boundaries - increased resistance to thermal shock and creep. 


\section{REFERENCES}

1. О. Бакай, В. Барьяхтар. Про загальні проблеми атомної енергетики України // Bопросы атомной науки и техники. Серия "Физика радиационных повреждений и радиационное материаловедение». 2017, №4(10), c. 107-110.

2. Nuclear Power in Ukraine. Available at: http:// world-nuclear.org / informatica-library / contriprofiles / countries-t-z / ukraine.aspx (accessed 08.11.17).

3. О.В. Сфімов, М.М. Пилипенко та ін. Реактори і парогенератори енергоблоків АЕС: схеми, проиеси, матеріали, конструкиії, моделі: Препринт ННЦ ХФТІ. Харьков: ННЦ ХФТИ, 2017, с. 120.

4. В.Н. Воеводин, И.М. Неклюдов. Эволюция структурно-фазового состояния и радиационная стойкость конструкиионных материалов. Киев: «Наукова думка», 2006, с. 376.

5. N.A. Azarenkov, V.E. Semenenko, A.V. Leonovich. Thermal stability of tungsten carbide materials // Reability and life of machines and structures. 2013, issue 37, p. 111-127.

6. H.B. Dong. Analysis of grain selection during direction solidification of gas turbine blades // Proc. of the World Congress on Engineering. 2007, v. 11, WCE 2007, July 2-4, London, UK.

7. Н.А. Азаренков, В.Е. Семененко, С.В. Литовченко, Н.Г. Стервоедов. Применение чистых материалов в атомной и нетрадиционной энергетике // Матеріали доповідей 5-ї Міжнародної конференції «Високочисті матеріали: отримання, застосування, властивості». 2019, вересень 10-13, Харків. Харків: ННЦ ХФТІ, с. 50-51.

8. Н.А. Азаренков, В.Е. Семененко, В.А. Позняков. Высокотемпературные естественные композиты // Металлофизика и новейшие технологии. 2011 т. 33, №12, с. 379-391.

9. Н.А. Азаренков, В.Е. Семененко, Н.Г. Стервоедов. Влияние диффузионных процессов на структурную стабильность естественных микроком- позитов // Вопросы атомной науки и техники. Серия "Физика радиационных повреждений и радиационное материаловедение». 2011, №2(97), с. 149-154.

10. Н.А. Азаренков, В.Е. Семененко, В.И. Ткаченко. Перспективные конструкционные материальг нетрадиционной энергетики. Харьков: ХНУ, 2016, c. 105.

11. Sang J. Choi, Ji Hyun. Radiation - Induced Dislocation and Growth Bahavior of Zirconium and Zirconium Alloys // Nuclear Engineering and Technology. 2013, v. 45, N 3, p. 385-392.

12. В.И. Изотов. Выделение дисперсных карбидов ванадия на межфазных границах при перлитном превращении сталей // Физика металлов и металловедение. 2011, т. 111, №6, с. 619-625.

13. V.M. Azhazha, V.E. Semenenko, A.S. Posukhov, N.N. Pilipenko. High strength and wear-resistant eutectic composite // Journal of Superhard materials. 2006, v. 28, N 5, p. 57-62.

14. Академик Владимир Михайлович Ажажа. Харьков: ННЦ ХФТИ, 2011, с. 12-21.

15. Н.В. Регель. Дисклинацุии в кристаллах. Санкт-Петербург, 2008, с. 278.

16. K.A. Terrari, S.S. Zinkle. Advanced irradiation-resistant iron-based alloys for LWR fuel cladding // Journal of Nuclear Materials. 2014, v. 448, p. 420435.

17. H. Mehrer. Diffusion in solids. Berlin: Springer, 2007, p. 305-371.

18. D. Marcus, B. Diaswara. Modelling of strength and passivation of iron-chromium alloys // Proc. of EUROCORE, 2013. Budapest, 2013, p. 121-126.

19. T. Tonabe, N. Noda. Preview of high strength materials for PSS application // ADV Materials. 2014 , v. 30, p. $81-94$.

20. П. Бриджмен. Исследование больших пластических деформаций и разрывов. М.: Изд-во иностр. лит-ры, 2016, с. 135-161.

\title{
ВЛИЯНИЕ ЧИСТОТЫ МАТЕРИАЛОВ НА МИКРОСТРУКТУРУ И ПРОЧНОСТНЫЕ ХАРАКТЕРИСТИКИ ТУГОПЛАВКИХ МИКРОКОМПОЗИТОВ
}

\author{
Н.А. Азаренков, В.Е. Семененко, С.В. Литовченко, Н.Г. Стервоедов
}

Исследовано влияние чистоты исходных материалов на структурную и размерную стабильность микрокомпозитов, получаемых в процессе контролируемого нонвариантного фазового превращения. Рассматривается влияние высокотемпературной посткристаллизационной термообработки на процессы очистки и повышения технологической пластичности конструкционных материалов. Обсуждается возможность их практического использования

\section{ВПЛИВ ЧИСТОТИ НА МІКРОСТРУКТУРУ І ХАРАКТЕРИСТИКИ МІЦНОСТІ ТУГОПЛАВКИХ МІКРОКОМПОЗИТІВ}

\section{М.О. Азарєнков, В.С. Семененко, С.В. Литовченко, М.Г. Стєрвоєдов}

Досліджено вплив чистоти вихідних матеріалів на структурну і розмірну стабільність мікрокомпозитів, отриманих у процесі контрольованого нонваріантного фазового перетворення. Розглядається вплив високотемпературної посткристалізаційної термообробки на процеси очищення та підвищення технологічної пластичності конструкційних матеріалів. Обговорюється можливість їх практичного використання. 